\title{
Surface charge impact in nonsynaptic model of epilepsy in rat hippocampus
}

\author{
O.S. Zapukhliak, V.O. Kachanovska, E.V. Isaeva, O.V. Netsyk, D.S. Isaev \\ O.O.Bogomoletz Institute of Physiology of National Academy of Science of Ukraine, Kyiv; \\ e-mail:dmytro.isaev@gmail.com
}

\begin{abstract}
Decreasing of surface charge screening near voltage-gated ion channels via reduction of extracellular cation divalent ions provide potent mechanism of altering cellular excitability and seizure threshold. Spontaneous field potentials were recorded from horizontal brain slices of young Wistar rats (postnatal day 10-12). Extracellular registrations wereobtained from CA1 and CA3 area of hippocampus. For induction of nonsynaptic epileptiform activity slices were perfused with artificial cerebrospinal fluid with omitted $\mathrm{Ca}^{2+}$ and $\mathrm{Mg}^{2+}$ ions. Effect of different $\mathrm{Mg}^{2+}$ concentration (1, 2, and 3mmol/l) on initial stage of nonsynaptic epileptiform discharges was studied. Our results suggest that the change in $\mathrm{Mg}^{2+}$ concentration dramatically affects the probability of induction of low-Ca ${ }^{2+}$ seizure-like activity (SLA), providing evidence that $\mathrm{Mg}^{2+}$ can alter cerebral excitability by affecting the surface charge and supporting the idea that surface charge could be a pharmacological target for anti-epileptic treatment.

Key words:low-Ca ${ }^{2+}$ seizure-like activity; surface charge; magnesium; hippocampus.
\end{abstract}

\section{INTRODUCTION}

Epileptic seizures are characterized by the abrupt and highly synchronous discharge of the neuronal net. During the seizures large neuronal aggregates are involved into excessive highly synchronized discharges that last several seconds or minutes [1]. It is well established that excitatory synaptic connections mediate the initiation and propagation of the epileptiform discharges [2]. However, in vitro experiments have shown that ictal epileptiform activity can be evoked in the absence of active chemical synaptic transmission [3]. In the 1980s two reports were published, each describing a dramatic form of neuronal synchronization in hippocampal slices exposed to media containing low concentration of $\mathrm{Ca}^{2+}[4,5]$. Later it was shown that not only CA1, but under certain conditions CA3 zone of the hippocampal slices could generate large and highly synchronized discharges that could last for many seconds [6]. These experiments revealed that epileptiform activity could have nonsynaptic origin, however it remained unclear which of the effects of reduction of extracellular $\mathrm{Ca}^{2+}$ can account for abnormal neuronal synchronization. Four types of nonsynaptic mechanisms are generally considered to account for neuronal synchronization: a) ephaptic transmission (between clusters of neurons with closely opposed membranes); b) field effects (during synchronous neuronal activity of large groups of neurons with a suitable, usually parallel, arrangement; c) electrotonic coupling through gap junctions; d) extracellular ions fluctuations (such as increase in $\mathrm{K}^{+}$) [7]. Altogether these nonsynaptic mechanisms dramatically alter neuronal excitability and exert influence on seizure threshold. Field effects and ion fluctuations may have modest effects during physiological activity but have a significant impact on epileptic seizures, and can sustain them in the absence of synaptic transmission. It is known, that field effects can contribute to seizure generation in vivo in a number of other clinical situations [8]. Infusion of low- $\mathrm{Ca}^{2+}$ solutions into brains of cats and other laboratory animals causes (C) O.S. Zapukhliak, V.O. Kachanovska, E.V. Isaeva, O.V. Netsyk, D.S. Isaev 
seizures $[9,10]$. Humans with low levels of extracellular $\mathrm{Ca}^{2+}$ can also develop seizures. For instance, convulsions can occur with vitamin D deficiency or hypoparathyroidism in which total blood $\mathrm{Ca}^{2+}$ concentration falls from its normal value[11].

At the cellular level, the hallmark feature of epileptiform activity is neuronal hyperexcitability. Surface charge on the cellular membrane produced by sialic acid, phosphates, charged lipids, charged amino acids, and other hydrophilic residues of channel proteins creates local electrical fields near the channel voltage sensor [12]. The effect of surface charge on the membrane channel can be assessed by changing extracellular concentrations of cations, which produce a screening effect on surface charge. Decreasing extracellular $\mathrm{Ca}^{2+}$ or increasing the amount of extracellular negatively charged polysialic acids results in a significant hyperpolarizing shift of activation of voltagegated $\mathrm{Na}^{+}$-channels $[12,13,14]$. In the present study, we investigated the effect of various $\mathrm{Mg}^{2+}$ concentrations in the extracellular solution on the probability to evoke seizure activity, its delay time and pattern of discharges.

\section{METHODS}

Animals. Wistar rat pups of postnatal day 12 (P12) were used throughout the study and treated in accordance with the guidelines set by the Animal Care Committee of Bogomoletz Institute of Physiology of NAS of Ukraine.

Slice preparation. Animalswere deeply anesthetized with sevoflurane and decapitated. Brain was rapidly removed and placed in icecold artificial cerebro-spinal fluid (aCSF). Cerebellum and frontal lobe of the brain were removed and transverse brain slices $(500 \mu \mathrm{m})$ were cut using vibroslicer [12]. The resulting slices were then transferred to the incubation chamber and left to recover for at least one hour before the experiment at room temperature. All manipulations were performed in constantly oxygenated $\left(95 \% \mathrm{O}_{2}-5 \% \mathrm{CO}_{2}\right)$ aCSF of the following composition (mmol/l): $125 \mathrm{NaCl}$, $3.5 \mathrm{KCl}, 1.3 \mathrm{MgCl}_{2}, 2 \mathrm{CaCl}_{2}, 1.25 \mathrm{NaH}_{2} \mathrm{PO}_{4}, 24$ $\mathrm{NaHCO}_{3}, 11$ glucose, $\mathrm{pH}=7.35$. All drugs were obtained from "Sigma" (USA).

Extracellular recordings. Spontaneous field potential recordings were obtained from CA 1 and CA3 pyramidal cell layers of rat hippocampus, using glass micropipettes (2$5 \mathrm{M}^{\prime} \Omega$ ) filled with aCSF. For induction and record of nonsynaptic SLA slices were transferred to the submersion-type chamber and perfused with the low- $\mathrm{Ca}^{2+}$ solution containing $(\mathrm{mmol} / \mathrm{l})$ : $115 \mathrm{NaCl}, 5 \mathrm{KCl}, 1 \mathrm{MgCl}_{2}, 1.25 \mathrm{NaH}_{2} \mathrm{PO}_{4}, 24$ $\mathrm{NaHCO}_{3}, 10$ glucose, $\mathrm{pH}=7.4$ (oxygenated with carbogen). Recordings were amplified with a differential amplifier, digitized at $10 \mathrm{kHz}$ using an analog-to-digital converter and stored using WinWCP program. All records were made at room temperature $\left(24-25^{\circ} \mathrm{C}\right)$. A total of 57 hippocampal slices was used throughout the study. The first group of slices $(n=10)$ was perfused with low- $\mathrm{Ca}^{2+}$ solution where $\mathrm{MgCl}_{2}$ was omitted from the perfusion solution. In subsequent recordings $\mathrm{MgCl}_{2}$ was added to the low- $\mathrm{Ca}^{2+} \mathrm{aCSF}$ in concentration of $1 \mathrm{mM}(\mathrm{n}=24)$, $2 \mathrm{mM}(\mathrm{n}=12)$ and $3 \mathrm{mM}(\mathrm{n}=11)$.

Data analysis. Off-line analysis was performed using Clampfit 10.2 (Axon Istruments), Origin 8.5 (OriginLab Northampton,MA). All data was represented as means \pm Se.

\section{RESULTS AND DISCUSSION}

In the present study we evaluated the role of surface charge in generation of nonsynaptic epileptiform discharges. The most dramatic example of nonsynaptic synchronization in mammals is the "field burst" [4] in hippocampal slices maintained in vitro, after chemical synaptic transmission has been blocked by removing extracellular $\mathrm{Ca}^{2+}[4,5,15-17]$. Both extracellular $\mathrm{Ca}^{2+}$ and $\mathrm{Mg}^{2+}$ concentration affect neuronal excitability by charge screening, where divalent cations attracted to negative charges on the neuronal membrane tend to increase the electric field that is sensed by channels within 
the membrane. Lowering the concentration of divalent cations reduces charge screening and reduces the field acting across the membrane that has the same effect as depolarizing the cell [7]. As we could not change $\mathrm{Ca}^{2+}$ concentration due to nature of the epileptic model, we altered extracellular $\mathrm{Mg}^{2+}$ concentration.

Perfusion hippocampal slices with low$\mathrm{Ca}^{2+}$ artificial CSF resulted in occurrence of spontaneous epileptiform discharges both in
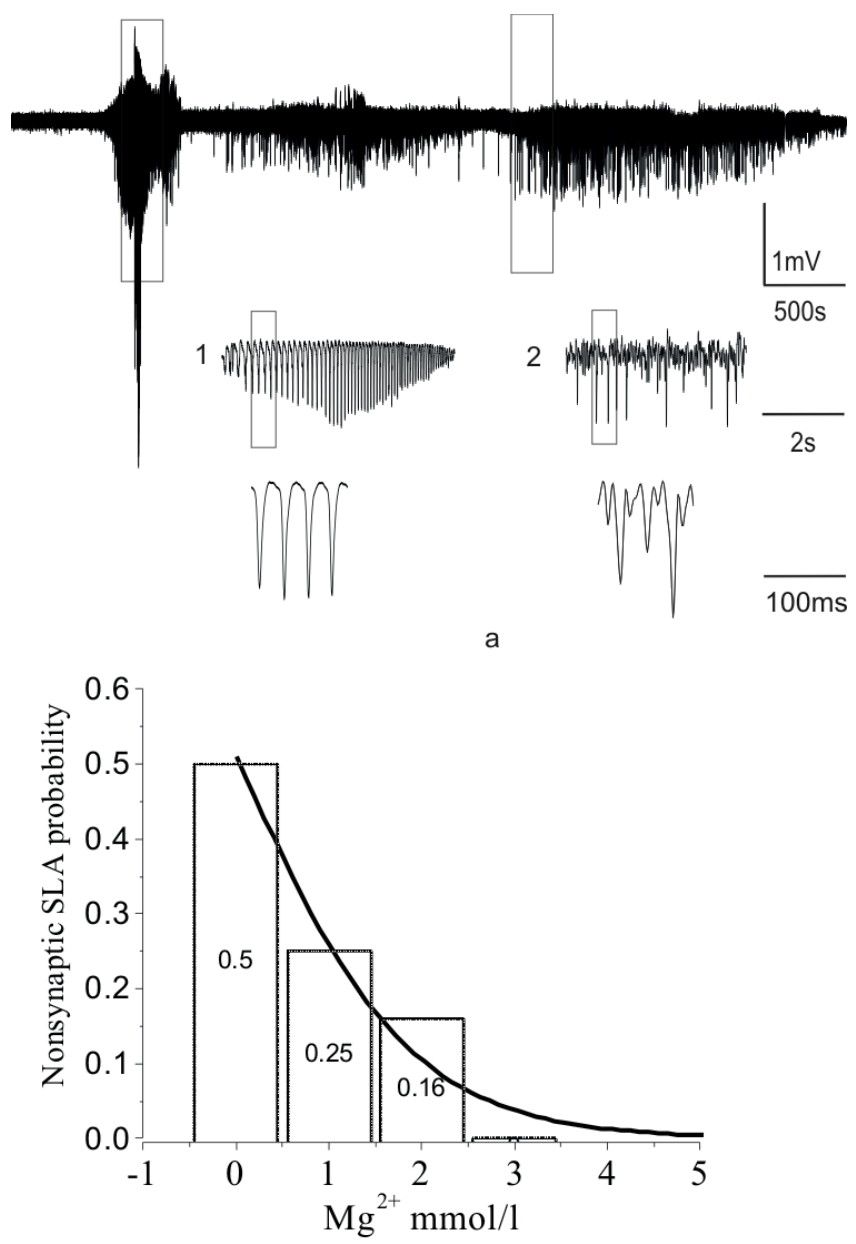

b

Fig.1. Manifestations of nonsynaptic epileptiform activity and probability of low- $\mathrm{Ca}^{2+}$-induced SLA dependent on extracellular magnesium concentration. a - extracellular recordings of spontaneous field potentials from CA1 area of hippocampus in low- $\mathrm{Ca}^{2+}$ solution. Two types of nonsynaptic discharges outlined with boxes: 1 - burst of waves with clock-like fashion; 2 - continuously firing population spikes; $b$ - cumulative histogram shows probability of induction of low- $\mathrm{Ca}^{2+}$ SLA under different extracellular $\mathrm{Mg}^{2+}$ concentrations; the curve represents theoretical probability statistically assessed with logistic regression
CA1 and CA3 hippocampal areas. However, the obtained probability of inducing nonsynaptic SLA in CA1 and CA3 zones was different depending on $\mathrm{Mg}^{2+}$ concentration in low- $\mathrm{Ca}^{2+}$ aCSF. Low $-\mathrm{Ca}^{2+} /$ low- $\mathrm{Mg}^{2+}$ solution induced nonsynaptic bursting in $50 \%$ of recorded slices (5/10) (Fig. 1). Epileptiform discharges occurred within delay time of $17 \pm 5 \mathrm{~min}$ in CA1 and $19 \pm 12$ min in CA3 zones. These nonsynaptic discharges represented population spikes that either were firing continuously or were arranged in bursts that could appear in clock like manner (Fig.1A). The frequency of population spikes in low- $\mathrm{Ca}^{2+} /$ low- $\mathrm{Mg}^{2+}$ solution was $0.75 \pm 0.01 \mathrm{~Hz}$ in CA 1 and $0.64 \pm 0.02$ in CA3 zone.

Next, we perfused hippocampal slices with low- $\mathrm{Ca}^{2+}$ aCSF with $1 \mathrm{mmol} \mathrm{Mg}^{2+}$. Under these conditions nonsynaptic bursting was induced in $30 \%$ of recorded slices $(6 / 18)$ (Fig. 1B) with the latency of $26 \pm 4.5$ min and $16 \pm 3.6 \mathrm{~min}$ in CA1 and CA3 pyramidal layer respectively. Population spikes had frequency of $0.72 \pm 0.06 \mathrm{~Hz}$ in $\mathrm{CA} 1$ and $0.7 \pm 0.04$ $\mathrm{Hz}$ in CA3 hippocampal area.

Perfusion of hippocampal slices with low-Ca ${ }^{2+}$ aCSF containing $2 \mathrm{mmol} \mathrm{Mg}^{2+}$ caused nonsynaptic bursting in $20 \%$ of recorded slices (2/10) (Fig. 1B). Under these conditions, population spikes were observed only in CA1 zone and had frequency of $0.59 \pm 0.07 \mathrm{~Hz}$.

We failed to induce spontaneous nonsynaptic bursting by perfusion hippocampal slices with low- $\mathrm{Ca}^{2+}$ aCSF containing $3 \mathrm{mmol} \mathrm{Mg}^{2+}(\mathrm{n}=11)$.

We showed that induction of nonsynaptic bursting in CA1 pyramidal layer is less influenced by an increase in extracellular magnesium concentration. It is known that low$\mathrm{Ca}^{2+}$ field bursts occur in parts of the brain with tightly laminar 
organization. The rodent hippocampal CA1 region is especially susceptible because its cell bodies form a very tight layer, where the geometry of a structure promotes the generation of large extracellular fields that alter the excitability of neighboring neurons [7]. Also, gap-junctions in CA1 pyramidal area are more developed especially in young animals [18].Our data suggest that an increase in extracellular $\mathrm{Mg}^{2+}$ concentration significantly and progressively decreased the probability of induction of seizure like activity in low- $\mathrm{Ca}^{2+}$ model of epilepsy. Both cellular depolarization and hyperpolarizing shift of the voltage-gated channel activation cause similar effects on neuronal network activity due to reduced voltage difference between the resting membrane potential and potentials where $\mathrm{Na}^{+}$-channels are activated. Removal of $\mathrm{Mg}^{2+}$ ions from extracellular solution shifts leftward the half activation and facilitates the amplitude of $I_{\mathrm{Na}}$ compared with the $1 \mathrm{mmol}$ $\mathrm{Mg}^{2+}$ solution [12]. Our results suggest that the change in the surface charge dramatically affects the probability of induction of low- $\mathrm{Ca}^{2+}$ SLA, providing evidence that $\mathrm{Mg}^{2+}$ can reduce cerebral excitability by screening surface charge and support the idea that lack of $\mathrm{Mg}^{2+}$ could cause epileptic seizures. In previous studies, it was shown that manipulations with surface charge could alter the pattern of epileptiform like activity [19]. In previous work we demonstrated that surface charge plays a crucial role in low$\mathrm{Mg}^{2+}$ model of epilepsy [12].

In the next set of experiments we estimated the effect of increased $\mathrm{Mg}^{2+}$ concentration on the ongoing low- $\mathrm{Ca}^{2+}$ epileptic discharges. Increasing $\mathrm{Mg}^{2+}$ concentration to $1 \mathrm{mmol}$ in perfusion solution abolished SLA evoked in low- $\mathrm{Ca}^{2+} / 10 \mathrm{w}-\mathrm{Mg}^{2+}$ aCSF in all tested slices $(n=4)$ (Fig 2). Further decrease in extracellular magnesium concentration intensified low- $\mathrm{Ca}^{2+}$ field bursts. However, earlier studies reported that nonsynaptic bursting in the low- $\mathrm{Ca}^{2+}[15]$ and zero- $\mathrm{Ca}^{2+}[20]$ models were suppressed by higher concentrations of extracellular $\mathrm{Mg}^{2+}$ in hippocampal slices from adult rats. The observed increased sensitivity to extracellular magnesium concentration in the immature hippocampus may be caused by age-specific conditions for excitation and inhibition processes in developing

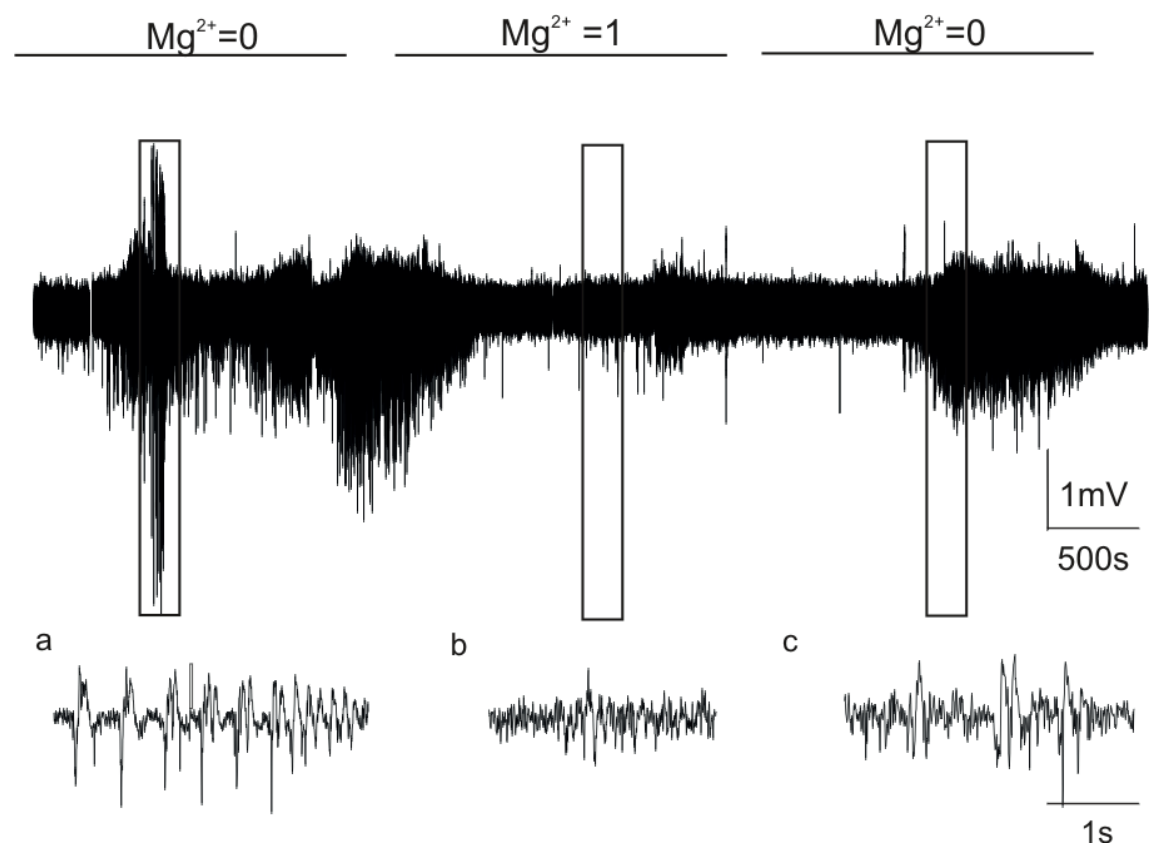

Fig 2. Effect of increasing extracellular $\mathrm{Mg}^{2+}$ concentration on low-Ca ${ }^{2+} / \mathrm{low}-\mathrm{Mg}^{2+}$ induced nonsynaptic bursting. Horizontal bars indicate $\mathrm{Mg}^{2+}$ concentration in low- $\mathrm{Ca}^{2+} /$ low- $\mathrm{Mg}^{2+}$ perfusion aCSF. Enlargements of extracellular field potentials record obtained in a - low-Ca ${ }^{2+} /$ low- $\mathrm{Mg}^{2+}$ solution, $\mathrm{b}-\mathrm{low}-\mathrm{Ca}^{2+} / 1 \mathrm{mmol} \mathrm{Mg}^{2+}, \mathrm{c}-$ washout 
brain. Thus, surface charge has greater impact in low- $\mathrm{Ca}^{2+}$ model of epilepsy in developing brain.

Under the low- $\mathrm{Ca}^{2+}$ conditions synaptic transmission is almost completely blocked from presynaptic side so our observations are different from other seizure models and demonstrate that manipulation with surface charge could significantly alter seizure susceptibility even under conditions of nonsynaptic neuronal synchronization. This study further suggests that surface charge may represent a potential therapeutic target in the treatment of epilepsy.

\section{CONCLUSIONS}

1.Low-Ca ${ }^{2+}$-induced nonsynaptic discharges in hippocampal slices characterized by population spikes that either were firing continuously or were arranged in field bursts that could appear in clock like manner.

2. Probability to trigger nonsynaptic SLA in low- $\mathrm{Ca}^{2+}$ model of epilepsy with preferential initiation in CA1 pyramidal layer of hippocampus intensified by lowering extracellular magnesium concentration.

3. Screening of the surface charge of the neuronal membranes through increasing of extracellular magnesium concentration abolished nonsynaptic field bursts induced by low- $\mathrm{Ca}^{2+}$ aCSF.

\section{О.С. Запухляк, В.О. Качановська, Е.В. Ісаєва, О.В. Нецик, Д.С. Ісаєв \\ ВПЛИВ ІОНІВ МАГНІЮ НА НЕСИНАПТИЧНІ ЕПІЛЕПТОПОДІБНІ ЯВИЩА В ГІПОКАМПІ ЩУРІВ}

Зниження поверхневого заряду поблизу потенціалкерованих іонних каналів через зменшення позаклітинної концентрації двовалентних катіонів впливає на клітинну збудливість тапоріг епілептиформної активності. Горизонтальні зрізи мозку молодих щурів лінії Вістар були використані для запису спонтанних польових потенціалів. Зовнішньоклітинні реєстрації отримано з зон СА1 та СА3 гіпокампа. Для індукції несинаптичних епілептоподібних явищ зрізи перфузували штучним спинномозковим розчином без додавання іонів магнію та кальцію. Нами було досліджено вплив різних концентрацій магнію (1,
2, 3ммоль/л) на початкову стадію несинаптичних епілептоподібних явищ у гіпокампі щура. Отримані результати показали, що зміна концентрації $\mathrm{Mg}^{2+}$ впливає на ймовірність виникнення низькокальцієвих епілептиформних явищ. Іони магнію беруть участь у створенні поверхневого заряду мембрани i, як наслідок, змінюють збудливість нейронів, що дає підставу розглядати поверхневий заряд мембрани як фармакологічну мішень у лікуванні епілепсії. Ключові слова: епілептиформні явища викликані у розчині з низькою концентрацією $\mathrm{Ca}^{2+}$; поверхневий заряд; магній; гіпокамп.

\section{О.С. Запухляк, В.А.Качановская, Е.В. Исаева, О.В. Нецык, Д.С. Исаев}

\section{ВОЗДЕЙСТВИЕ ИОНОВ МАГНИЯ НА НЕСИНАПТИЧЕСКИЕ ЭПИЛЕПТИФОРМНЫЕ РАЗРЯДЫ В ГИППОКАМПЕ КРЫС}

Снижение поверхностного заряда вблизи потенциалуправляемых ионных каналов путем уменьшения внеклеточной концентрации двухвалентных катионов влияет на клеточную возбудимость и порог эпилептиформной активности. Горизонтальные срезы мозга молодых крыс линии Вистар были использованы для записи спонтанных внеклеточных полевых потенциалов. Регистрации были получены из зон СА1 и СА3 гиппокампа. С целью индукции несинаптичных эпилептиформных явлений срезы перфузировали искусственным спинномозговым раствором без добавления ионов магния и кальция. В данной работе было исследовано влияние различных концентраций магния $(1,2$, 3ммоль/л) на начальную стадию несинаптической эпилептиформной активности в гиппокампе крысы. Полученные результаты показали, что изменение концентрации магния влияет на вероятность возникновения низкокальциевых эпилептиформных явлений. Ионы магния участвуют в создании поверхностного заряда мембраны и, как следствие, влияют на возбудимость нейронов, что дает основание рассматривать поверхностный заряд мембраны в качестве фармакологической мишени в лечении эпилепсии.

Ключевые слова: эпилептиформные явления вызванные в растворе с низкой концентрацией $\mathrm{Ca}^{2+}$; поверхностный заряд; магний; гиппокамп.

\section{REFERENCES}

1. DichterMA, Herman CJ, Selzer M. Silent cells during interictal discharges and seizures in hippocampal penicillin foci. Evidence for the role of extracellular $\mathrm{K}^{+}$ in the transition from the interictal state to seizures. Brain Res.1972;48:173-83.

2. Prince DA, Connors BW. Mechanisms of interictalepileptogenesis.Adv Neurol. 1986; 44:275-99.

3. Bikson M, Baraban SC, Durand DM. Conditions sufficient for nonsynaptic epileptogenesis in the CA1 region of 
hippocampal slices. JNeurophysiol. 2002; 87: 62-71.

4. Jefferys JG, Haas HL. Synchronized bursting of CA1 hippocampal pyramidal cells in the absence of synaptic transmission. Nature. 1982; 300(5891): 448-50.

5. TaylorCP,DudekFE. Synchronous neural afterdischarges in rat hippocampal slices without active chemical synapses. Science Wash. 1982; 218(4574): 810-12.

6. SnowRW, DudekFE. Synchronous epileptiform bursts without chemical transmission in CA2, CA3 and dentate areas of the hippocampus. Brain Res.1984; 298(2):382-5.

7. Jefferys JG. Nonsynaptic modulation of neuronal activity in the brain: electric currents and extracellular ions. Physiol Rev. 1995; 75 (4): 689-723.

8. Traub RD, Dudek FE, Snow RW, Knowles WD. Computer simulations indicate that electrical field effects contribute to the shape of the epileptiform field potential. Neuroscience. 1985; 15(4): 947-58.

9. Kaczmarek LK, Adey WR. Extracellular release of cerebral macromolecules during potassium- and lowcalcium-induced seizures.Epilepsia. 1975; 16(1): 91-7.

10. Feng Z, Durand DM. Low-calcium epileptiform activity in the hippocampus in vivo. J Neurophysiol. 2003; 90(4): 2253-60.

11. Oki J1, Takedatsu M, Itoh J, Yano K, Cho K, Okuno A. Hypocalcemic focal seizures in a one-month-old infant of a mother with a low circulating level of vitamin D. Brain Dev. 1991; 13(2): 132-4.

12. Isaev D, Ivanchick G, Khmyz V, Isaeva E, Savrasova A, Krishtal O, Holmes GL, Maximyuk O. Surface charge impact in low-magnesium model of seizure in rat hippocampus. J Neurophysiol. 2012; 107: 417-23.
13. Bennett E, Urcan MS, Tinkle SS, Koszowski AG, Levinson SR. Contribution of sialic acid to the voltage dependence of sodium channel gating. A possible electrostatic mechanism. J Gen Physiol. 1997; 109(3): 327-43.

14. Isaeva E, Lushnikova I, Savrasova A, Skibo G, Holmes GL, Isaev D. Blockade of endogenous neuraminidase leads to an increase of neuronal excitability and activitydependent synaptogenesis in the rat hippocampus.Eur $\mathbf{J}$ Neurosci.2010;32(11):1889-96.

15. Haas HL, Jefferys JGR. Low-calcium field burst discharges of CA1 pyramidal neurons in rat hippocampal slices. J PhysiolLond. 1984; 354: 185-201.

16. Konnerth A, Heinemann U, Yaari Y. Slow transmission of neural activity in hippocampal area CA1 in absence of active chemical synapses. Nature. 1984; 307(5946): 69-71.

17. Taylor CP, Dudek FE. Synchronization without active chemical synapses during hippocampal afterdischarges. J Neurophysiol. 1984; 52(1):143-55.

18. Perez-VelazquezJL, Valiante TA, Carlen PL.Modulation of gap junctional mechanisms during calcium-free induced field burst activity: a possible role for electrotonic coupling in epileptogenesis.JNeurosci.1994;14(7):4308-17.

19. Isaev D, Isaeva E, Shatskih T, Zhao Q, Smits NC, Shworak NW, Khazipov R, Holmes GL. Role of extracellular sialic acid in regulation of neuronal and network excitability in the rat hippocampus. J Neurosci.2007;27(43):11587-94.

20. Bikson M, Ghai RS, Baraban SC, Durand DM. Modulation of burst frequency, duration, and amplitude in the zero$\mathrm{Ca}(2+)$ model of epileptiform activity. J Neurophysiol. 1999;82(5): 2262-70.

Received 09.11.2015 